\title{
MULTIPLE INTELLIGENCE AND STUDENTS' LEARNING MOTIVATION THROUGH DEMONSTRATION WITH OUTDOOR ACTIVITIES
}

\author{
Lilis Lismaya \\ Department of Biology Education, Faculty of Teacher Training and Education, Universitas Kuningan, Indonesia \\ E-mail: lilis.lismaya@uniku.ac.id
}

\begin{abstract}
APA Citation: Lismaya, L. (2020). Multiple intelligence and students' learning motivation through demonstration with outdoor activities. Indonesian Journal of Learning and Instruction, 3(1), 19-26. doi: 10.25134/ijli.v3i1.3004.
\end{abstract}

\begin{abstract}
This research is motivated by learning that is still dominantly carried out in the classroom, learning emphasizes more on the aspects of knowledge, so students feel bored and lack the awareness to care for the environment well, lack of concern for the surrounding environment. The ability of students who are still lacking in terms of classifying the types of plant leaves shows Biology learning requires a different learning method, one of which is using the Demonstration with Outdoor Activities Method. The purpose of this study is to analyze Multiple Intelligence and Student Learning Motivation through Demonstration Method with Outdoor Activities. The research method used is weak experimental research design The OneGroup Pretest-Posttest Design. The instruments used in this study were multiple intelligence questions, observation sheets and questionnaires. The results showed that the application of the Demonstration with Outdoor Activities Method can increase multiple intelligence and Student Learning Motivation, because the Demonstration with Outdoor Activities Method is learning done outside the classroom by means of students practicing and being invited to look for material learned, so learning does not feel boring. Based on the results of the study, it was concluded that there was an increase in Multiple Intelligences and student learning motivation through the application of the Demonstration with Outdoor Activities method.
\end{abstract}

Keywords: multiple intelligence; motivation; demonstration; outdoor activities.

\section{INTRODUCTION}

Along with the times, education has also changed. This has resulted in changes in policies in the field of education so as to cause schools to also make changes in methods and learning strategies that are appropriate to achieve the desired learning goals (Herliani, 2015).

Improving the quality of education in schools can be done through various ways, including through curriculum improvement, increasing teacher competency, improving the quality of learning, the effectiveness of learning methods, improving the quality of learning facilities and infrastructure and adequate teaching materials (Sukitman, 2015).

Education is a conscious and planned effort to create an atmosphere of learning and learning process so that students are actively able to develop their potential to have spiritual strength, self-control, personality, intelligence, noble character and the skills needed by themselves, society, nation and state (Sudjana, 2010). Learning is a conscious and deliberate effort by the teacher to make students actively learn in developing their thinking creativity. The main purpose of organizing learning activities is to teach students to be able to process and obtain knowledge, skills and attitudes for themselves. Students are expected to be motivated and happy to do interesting and meaningful learning activities. This means that the learning method is very important (Arends, 2008).

Meaningful learning will bring students to a memorable learning experience. The experience gained by students will be more memorable if the learning process they obtain is the result of their own understanding and discovery (Khasanah, 2016). In this context students experience and do it themselves. The learning process that takes place fully involves students to formulate their own concepts. The involvement of lecturers is only as a facilitator and moderator in the learning process.

Learning activities so far have only taken place in classrooms by utilizing monotonous learning resources and have not utilized outdoor activities, so that lecturers have difficimplementing varied learning activities (Erlangga, 2014). As a result, learning about plant morphology is rigid and formal. In response to these conditions, it is worth remembering Paulo Freire's statement which says that every 
place is a school, everyone is a teacher. This means that everyone is a teacher, the teacher can be anyone, anywhere, and be present at any time without limits of space, time, and any conditions (Lismaya, 2011). Thus anyone can become a teacher and learning does not have to take place in the classroom, because every place can be a place for learning. The Paulo Freire concept is very appropriate when it is connected with outdoor activities. Outdoor activities can be one alternative for enriching learning resources. Outdoor activities allow students to experience the concepts learned firsthand. This is because learning material is an activity that is close to the experience of students in their daily lives so that it becomes meaningful for life.

Learning is an activity involving teachers and students. The succes of teaching and learning process are influenced by student learning motivation. The exixtence of student learning motivation will give spirit and learning becomes more focused for students.. Motivation also determines the interesf of students in learning (Emda, 2017).

Biology is concerned with finding out about nature systematically, biology is not only the mastery of a collection of knowledge in the form of facts, concepts, or principles, but also a process of discovery. So that learning does not have to be done in the classroom alone, students do not feel confined in the room alone to achieve learning objectives, because through learning biology is expected to be a vehicle for students to learn themselves and the natural surroundings, as well as the prospects for further development in applying it in everyday life. The learning process emphasizes providing direct experience to develop competencies in order to explore and understand the nature around scientifically. Biology education is directed to inquiry and acting so that it can help students to gain a deeper understanding of the natural surroundings.

Education is not just a way to gain knowledge, but education is an effort to increase understanding, attitudes and skills and selfdevelopment of students. This ability or competency is expected to be achieved through various learning processes in schools. One of the learning processes that can be used to achieve the above competencies is through learning outside the classroom (Outdoor Activities).

Outdoor activities are one way how we increase student learning capacity. Students can learn more deeply through objects encountered than if learning in a classroom that has many limitations. Furthermore, learning outside the classroom can help students apply their knowledge. In addition, Outdoor activities are more challenging for students and bridging between theories in books and reality in the field (Nugroho, 2016). The quality of learning in real situations will provide increased capacity for learning achievement through the object being studied and can build better social and personal skills. Outdoor activities can be done at any time in accordance with the program design made by the lecturer.

Outdoor activities are learning that is done outside the classroom or outside the school building, or in the wild, such as playing in the environment around the school, in the park, or in the surrounding community so that knowledge and values are obtained related to the learning outcomes, for material delivered outside the classroom (Rohim, 2018).

Outdoor activities are the approach taken by the lecturer, where the lecturer invites students to study outside the classroom to see live events in the field that are used as learning resources. The role of the lecturer here is as a motivator, meaning that the lecturer is a guide so students learn through the experience they have gained.

This approach consciously exploits the potential of the natural setting to contribute to physical and mental development. By increasing awareness of reciprocal relationships with the environment, programs can change attitudes and behaviors towards the environment that they gain through hands-on experience outside the classroom. Second, the concept of outdoor activities is an approach using outdoor life that provides many opportunities for students to acquire and master various forms of basic skills, attitudes and appreciation of various things that are outside the classroom.

Dual intelligence is based on biological potential, which is then expressed as a result of genetic and environmental factors that influence each other (Gangadevi, 2014). Howard Gardner expands the scope of human potential beyond the limits of IQ scores through Multiple Intelligence theories. Multiple intelligence is the ability to solve problems or create an effective or valuable product in a certain background (Hasan, 2017).

Some previous studies on outdoor activities that have been carried include the research done by Asiah (2014), namely the application of outdoor activities in science learning to improve student learning outcomes. From these studies the result obtained that student's cognitive learning 
completeness classically has increased. Likewise with the affective and psychomotor learning outcomes of students has increased also.

In addition, similar research has also been done by Nababan (2019), which is about the aplication of outdoor activity learning models in improving student's learning outcomes. From these studies the results obtained that the learning outcomes of class XI students of SMAN 1 Pahae Julu Tapanuli Regency increases through the use of outdoor activity learning models. It is proved by the increased value of student completeness.

The two previous studies provide input for researcher conduct further research by modifiying learning methods anf determining different dependent variables, with the hope that they can both achieve the stated reseearch objectives. The research that I did was "Multiple Intelligence and Students' learning Motivation through Demonstration with Outdoor Activities". this research is important to investigate because so far there are still many students who feel bored and less motivated in learning due to the use of learning methods that are not in accordance with the characteristics of the material and students. therefore I feel interested to do this research.

\section{METHOD}

The research method used in this study is weak experimental with the research design of The One-Group Pretest-Posttest Design (Fraenkel, 2007). This study only used experimental class given treatment to assess the effect of the treatment without comparing with control class. The design of the research design is as follows:

Table 1. Research design the one-group pretest-

\begin{tabular}{ccc}
\multicolumn{3}{c}{ posttest design } \\
\hline $\mathrm{O}$ & $\mathrm{X}$ & $\mathrm{O}$ \\
Pretest & Treatment & Posttest \\
\hline
\end{tabular}

The populations in this study were all students of Biology Education study programs, Kuningan University, totaling 98 students. The sample used in this study was taken by purposive sampling of 1 class, namely the level of 1 semester one of the students of Biology Education Study Program FKIP Kuningan University with a total of 16 students namely students who are taking Plant Morphology courses.

The instrument used was a written test in the form of essay questions, which contained indicators to measure multiple intelligence, observation sheets and questionnaires. Tests are given at the beginning and end of learning. Observation sheets are used to analyze multiple intelligences of students. Questionnaire is to measure students' motivation. Data processing and analysis is performed by statistical tests, activities include scoring for pretest and posttest, calculating N-gain, data analysis using Statistical Package for Social Science (SPSS) for Windows version 16.0.

\section{RESULTS AND DISCUSSION}

The results of the validity and instrument reliability tests get the data described in Table 2 .

\begin{tabular}{cccc}
\multicolumn{4}{c}{ Table 2 . The result of trial validity and reliability } \\
\hline No & Statistic test & Score & Remark \\
\hline 1. & Validity test & 0,56 & Moderate \\
2. & Reliability test & 0,60 & Moderate \\
\hline
\end{tabular}

The results of the trial analysis which included the validity test showed a value of 0.56 meaning that all multiple intelligence questions had moderate validity. The reliability test results showed a value of 0.60 meaning that overall the multiple intelligence questions had medium category reliability.

Based on the results of the validity and reliability test, it can be concluded that the multiple intelligence problem can be used as an instrument in further research. To find out how to apply the Demonstration with Outdoor Activities Method to Multiple Intellegencies and student motivation, the results of pre-test and post-test was tested. The following in Table 3 presented the results of the average pre-test and post-test experimental class.

Table 3. The average result of pre-test and posttest of multiple intellegencies

\begin{tabular}{cccc}
\hline \multirow{2}{*}{ Class } & Number of students & \multicolumn{2}{c}{ Multiple Intellegencies } \\
\cline { 3 - 4 } $\begin{array}{c}\text { Experimental } \\
\text { class }\end{array}$ & 16 & 72,6 & Pre test average \\
\hline
\end{tabular}

Table 3 shows the average pretest results of the experimental class is 72.6. After learning by using the Demonstration with Outdoor Activities
Method, then a post test is given to see the Multiple Intelligences and student motivation. 
Lilis Lismaya

Multiple intelligence and students' learning motivation through demonstration with outdoor activities

The post test results showed the number 76.35 with a maximum value of 83 . The results of the analysis of Multiple Intelligences of students based on the pre-test and post-test average values can also be seen in Figure 1.

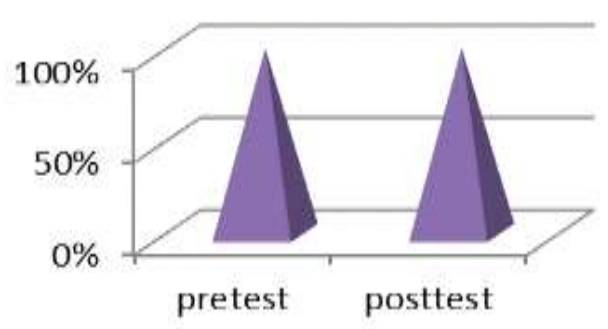

Figure 1. The average of pre test dan post test

From the results of statistical tests, the data obtained were normally distributed and homogeneous, so the hypothesis testing was carried out using the parametric statistical t test, the Independent Sample Test. $\mathrm{T}$ test was conducted to determine the significance level of the difference in the experimental class compared to KKM in Plant Morphology. The results of testing with a complete multiple intelligence $t$ test can be seen in Table 4 .

Table 4. The result of t test of multiple intelligence

\begin{tabular}{cccccc}
\hline $\begin{array}{c}\text { Data } \\
\text { source }\end{array}$ & Class & $\begin{array}{c}\text { Average } \\
\text { score }\end{array}$ & Significance & A & Remark \\
\hline Post test & Eksperimen & 73 & 0,000 & 0,05 & $\begin{array}{c}\text { Significant } \\
\text { difference }\end{array}$ \\
\hline
\end{tabular}

Based on Table 4.5 it can be seen that the results of the $t$ test show a significance of $0.00<\alpha$ $(\alpha=0.05)$, so it can be concluded that there is a significant multiple intelligence difference in the experimental class compared to the KKM of plant morphology courses.

Based on the results of the analysis of the overall experimental class in the $t$ test, it showed that there were significant differences in multiple intelligence compared to KKM in Plant Morphology. Both of these indicate that there is an effect of applying the Method Demonstration with Outdoor Activities on learning plant morphology towards multiple student intelligence on leaf material and plant branching patterns.

To find out the increase in multiple intelligence results in the experimental class as a whole based on the results of the Pre-test and Post-test, calculated using the $\mathrm{N}$-gain formula and then classified. The recapitulation of $\mathrm{N}$-gain calculation results is described in Table 5 .

Table 5. The result of $N$-gain test

\begin{tabular}{ccc}
\hline Class & Score & Category \\
\hline Eexperiment & 0,5 & Medium \\
\hline
\end{tabular}

From table 5 above it can be seen that the Ngain value obtained in the experimental class as a whole is 0.5 in the medium category, meaning that the application of the Demonstration with Outdoor Activities Method in learning Plant Morphology can increase student multiple intelligence by 0.5 in the medium category.
Furthermore, normality and homogeneity were tested for the multiple intelligence gain of students. Normality and homogeneity tests are used as a prerequisite for subsequent statistical tests. The results of the normality test calculation of the gain value of the problem solving skills of the experimental class as a whole are shown in Table 6.

Table 6. The result of normality test of $\mathrm{N}$-gain

\begin{tabular}{cccc}
\hline \multirow{2}{*}{ Data } & \multicolumn{3}{c}{ Tes Multiple intelligence } \\
\cline { 2 - 4 } & P-value & A & Remark \\
\hline N_Gain & 0,5 & 0,05 & Normal \\
\hline
\end{tabular}


The results of data normality testing with Kolmogorov-Smirnov results obtained experimental class gain values derived from populations that are normally distributed with a P-value of 0.50 greater than $\alpha=0.05 .=0.05$ and obtained the P-value as presented in Table 7.

Table 7. The result of homogeneity test of $N$-gain

\begin{tabular}{ccccc}
\hline & \multirow{2}{*}{ N } & \multicolumn{3}{c}{ Multiple intelligence } \\
\cline { 3 - 5 } & & P-value & A & Remark \\
\hline N_Gain & 16 & 0,5 & 0,05 & Homogenous \\
\hline
\end{tabular}

Based on table 7 it is known that the Multiple Intelligence gain value of students at the significance level $\alpha=0.05$ meets the P-value criterion $\alpha \alpha=0.05$, this means that the data variance is homogeneous.

From the results of statistical tests, the data obtained were normally distributed and homogeneous, so the hypothesis testing was carried out using the parametric statistical t test, the Independent Sample Test. $T$ test was conducted to determine the level of significance of increasing multiple intelligence of students, $t$ test results showed a significance of $0.00<\alpha(\alpha=$ 0.05 ), so it can be concluded that an increase in student multiple intelligence after the application of the Demonstration with Outdoor Activities Method in learning plant morphology.

Multiple intelligence in this study includes several indicators, including based on the results of analysis of tests given to students, namely: a) classifying nature; b) conducting an investigation (Hands-on Investigation); c) conducting simulations (Nature Simulations); d) caring for nature; e) Sensitive to natural phenomena (Natural Patterns) (Lazear, 2004).

Based on the results of the researchers' analysis, it turns out that through the application of the Demonstration with Outdoor Activities Method, it can be seen that students' ability to classify nature, especially the types of leaves and plant branching patterns in Kuningan Botanical Garden (KRK) has increased, this can be seen from the results of the student's post test and observation sheets. used during the learning.
Likewise, the ability of students in conducting investigations both individuals and groups appears to increase, they look more enthusiastic in conducting investigations in the open space.

Based on the results of researchers' observations, it appears that students also look more concerned and sensitive to nature, because through the application of the Demonstration with Outdoor Activities Method students are trained to love nature more, not to damage nature. They are also more enthusiastic in planning conservation activities for the environment. Multiple intelligence is the intelligence possessed by individuals towards plants, animals and the surrounding natural environment. Individuals who have high multiple intelligences will have high interest and love for plants and animals of the universe. He will not carelessly cut trees. He will not carelessly kill and torture animals. And he will also tend to maintain the environment where he is. He will love plants, animals and the environment as he loves himself. This is a high naturalist intelligence (Lazear, 2004).

In this study a measurement of student learning motivation was carried out through the application of the Demonstration with Outdoor Activities Method. Measurements were made through giving questionnaires to experimental class students. The questionnaire made included 6 indicators which were then developed into several questions. A recap of the percentage of student motivation through the application of the Demonstration with Outdoor Activities Method to learning plant morphology is shown in Figure 2.

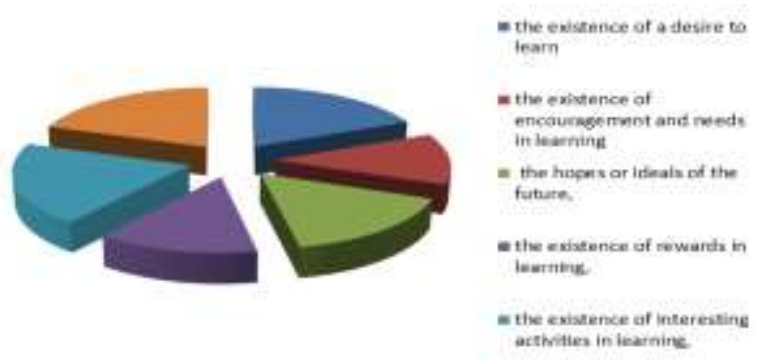

Figure 2. The result of students' motivation questionnaire 
Based on Figure 2, it can be seen that almost all indicators of student motivation show relatively high numbers. As for the motivational indicators measured include 6 indicators according to Uno (2011), namely: 1) the existence of a desire to learn, 2) the existence of encouragement and needs in learning, 3) the hopes or ideals of the future, 4) the existence of rewards in learning, 5) the existence of interesting activities in learning, 6) the existence of a conducive learning environment.

The first indicator is the existence of a desire to learn, from the results of the questionnaire seen that there are 15 students who agree that the implementation of Demonstration with Outdoor Activities can increase student learning desires. This is consistent with the results of field observations that students look enthusiastic when observing demonstrations of leaf shape recognition, leaf reinforcement, and stem branching patterns. Because they can see and practice directly the observation of plant morphology in Kuningan Botanical Garden.

The second motivational indicator is the existence of encouragement and needs in learning. The results of the questionnaire showed 10 students who agreed that through the application of the Demonstration with Outdoor Activities method, it could increase the motivation and learning needs of students. Although this figure shows the lowest number when compared with other motivational indicators. However, this still shows an increase in motivation in students.

The third indicator is the existence of hopes or ideals of the future showing the number 13 students who agreed that the application of the Demonstration with Outdoor Activities method can increase their motivation to learn because they have hopes and ideals in the future. Likewise with the fourth indicator which is the appreciation of learning. 11 students agreed that this appreciation in learning could increase student motivation, because they felt valued and recognized for their abilities.

The fifth indicator is the presence of interesting activities in learning, and the sixth indicator is the existence of a conducive learning environment. All students agreed that the application of the Demonstration with Outdoor Activities method could increase student motivation, especially because through learning outside the classroom they felt more interested in learning, because the learning environment was conducive so that learning activities were not monotonous like when they studied in class. They have a greater chance to explore all their competencies. This is in line with research conducted by Lismaya (2018) regarding outdoor activities that outdoor activities can improve student multiple intelligence, especially naturalist intelligence in learning plant morphology.

\section{CONCLUSION}

Based on the results of the study, it was concluded that there was an increase in Multiple Intelligences and student learning motivation through the application of the Demonstration with Outdoor Activities method. This is evidenced by the results of the $\mathrm{N}$ gain test which shows a value of 0.5 means that there is a significant increase of multiple intelligence students. Indicators of multiple intelligence measured and experiencing improvements in this study include 1) classifying nature; 2) conducting an investigation (Hands-on Investigation); 3) conducting simulations (Nature Simulations); 4) caring for nature; 5) Being sensitive to natural phenomena (Natural Patterns).

Increased motivation is evidenced through the results of the analysis of student motivation questionnaires covering the six motivational indicators, namely 1) the desire to learn, 2) the encouragement and needs in learning, 3) the hopes or ideals of the future, 4) the existence of appreciation in learning, 5) there are interesting activities in learning, 6) the existence of a conducive learning environment.

Based on the results of the study, then I give a few suggestions to complete this research, including: 1) When learning, good time management is needed between each stage of learning Demonstration with Outdoor Activities and at the end of the activity needs to be strengthened concepts., 2) When determining the place for learning, it should be adjusted to the learning material to be discussed so that it is right on target.

\section{REFERENCES}

Anderson, L.W. \& D.R. Krathwohl. ( 2001). Kerangka Landasan Untuk Pembelajaran, Pengajaran Dan Asesmen Agung Prihantoro (penerjemah). Yogyakarta : Pustaka Pelajar.

Ardimen. (2016). Pengembangan multiple intelligence melalui pembelajaran integratif berbasis games. Jurnal Edukasi, 2(2), 107-129.

Arends, R.I. (2008). Learning to Teach (Seventh Edition). New York: Mc Graw-Hill Companies.

Arikunto, S. (2007). Dasar-Dasar Evaluasi Pendidikan. Jakarta: Bumi Aksara. 
Asiah. (2014). Penerapan metode outdoor activity dalam pembelajaran IPA untuk meningkatkan hasil belajar siswa sekolah dasar. JPGSD, 02(3), $1-11$.

Blum., Niss, B., \& Stein, B. S. (2010). How to Assess Higher-Order Thingking Skills In Your Classroom. Alexandria: Virginia USA, ASCD.

Emda, A. (2017). Kedudukan motivasi belajar siswa dalam pembelajaran. Lantanida Journal, 5(2), 93-196.

Erlangga, A. (2014). Pengaruh metode pembelajaran demonstrasi terhadap minat belajar siswa kelas X di SMK Negeri 3 Singaraja. e jurnal JJPTE, 3(1), 125-135.

Fraenkel, J. R \& Wallen, N. E. (2007). How to Design and Evaluate Reseach in Education. San Francisco: McGraw-Hill Higer Education.

Gangadevi.S, Ravi. (2014). Multiple intelligence based curriculum to enhance inclusive education to bring out human potential. International Journal of Advanced Research. 2(8), 619-626.

Hasan, N. (2017). Penerapan multiple intelligences guna menumbuh kembangkan kreatifitas siswasiswi di SMK Kartika Grati, Kabupaten Pasuruan. Jurnal Kajian Islam, 2(1), 134-142.

Herliani, R.N. (2015). Penerapan metode demonstration with outdoor activities dalam mata pelajaran sosiologi materi perilaku menyimpang untuk meningkatkan motivasi dan hasil belajar siswa kelas X IPS MAN Kota Blitar. Jurnal Penelitian Sosial dan Ekonomi Kehutanan. 2(1).

Khasanah, Dwiastuti, \& Nurmiyati. (2016). The influence of guided discovery learning model toward scientific literacy based on naturalist intelligence. Proceeding Biology Education Conference. 13(1), 346-351.

Lazear, D. (2004). Higher-Order Thinking the Multiple Intelligences Way. Chicago : Zephyr Press.
Lismaya, L. (2011). Penerapan pembelajaran everyone is a teacher here pengaruhnya terhadap kemampuan argumentasi dan prestasi mahasiswa biologi (tingkat I) FKIP UNIKU. Quagga Jurnal Pendidikan dan Biologi. 3(1), 35-45.

Lismaya, L. (2018). Improving student's naturalist intelligence through outdoor activities on plant morphology learning. Indonesian Journal of Learning \& Instruction. 1(1), 47-52.

Nababan. (2019). Penerapan model pembelajaran outdoor activity dalam meningkatkan hasil belajar geografi. Jurnal Global Edukasi, 3(1), 1318.

Nugroho, Hanik. (2016). Implementation of outdoor learning to improve students cognitive learning outcomes on high plant systematics course. Bioedukasi. 9(1), 41-44.

Rohim, Asmana. (2018). Efektivitas pembelajaran di luar kelas (outdoor activities) dengan pendekatan PMRI. Jurnal Elektronik Pembelajaran Matematika. 5(3), 217-229.

Sudjana, N. (2010). Dasar-Dasar Proses Belajar Mengajar. Bandung: Sinar baru algesindo.

Sugiyono. 2010. Metode Penelitian Pendidikan Pendekatan Kuantitatif, Kualitatif dan $R \& D$. Bandung: Alfabeta.

Sukitman. (2015). Konsep pembelajaran multiple intelligence dalam pendidikan IPS di Sekolah Dasar. Jurnal Ilmiah Fakultas Keguruan dan Ilmu Pendidikan, 18(1), 1-12.

Wibawa, C. (2007). Perbedaan efektivitas metode demonstrasi dengan pemutaran video pemberantasan DBD terhadap peningkatan pengetahuan dan sikap siswa. Jurnal Promosi Kesehatan Indonesia, 2(2), 145-156.

Uno, B.H. (2011). Teori Motivasi dan Pengukurannya: Analisis di bidang Pendidikan. Jakarta: Bumi aksara. 
Lilis Lismaya

Multiple intelligence and students' learning motivation through demonstration with outdoor activities 